University of Warwick institutional repository: http://go.warwick.ac.uk/wrap This paper is made available online in accordance with publisher policies. Please scroll down to view the document itself. Please refer to the repository record for this item and our policy information available from the repository home page for further information.

To see the final version of this paper please visit the publisher's website. Access to the published version may require a subscription.

Author(s): Christopher W. Hughes

Article Title: Reflections on Globalisation, Security and 9/11

Year of publication: 2002

Link to published version:

http://dx.doi.org/10.1080/0955757022000010953

Publisher statement: none 


\title{
Reflections on Globalisation, Security and 9/11
}

\section{Christopher W. Hughes}

\begin{abstract}
The study of globalisation carries important conceptual insights into the contemporary security agenda following the events of 9/11. This article argues that globalisation can be defined in a variety of ways, ranging from liberalisation to Westernisation, and can also be extended into concepts of supra-territorialisation. In combination, these definitions help to explain the generation of 9/11 style-conflict by providing the political-economic motivation for hyper-terrorism, by facilitating the political identities and activities of non-state actors; and by creating an environment for the global reach of terror movements. Additionally, the interconnection between globalisation and security can be seen in the response of the US to 9/11 and its striving to project military power on a global scale with declining reference to time and geographical distance, and the varied ability of sovereign states to respond to the challenge of trans-sovereign security problems in the future.
\end{abstract}

Security has once again reclaimed the centre stage of the international social science and policy agendas. The events of 11 September 2001 and the ensuing conflict in Afghanistan have highlighted many of the unfolding trends and complexities of contemporary security. A variety of social science disciplines, including International Relations (IR) and the traditionally diverse field of Security Studies, have already been brought to bear in order to provide explanatory insights into the aftermath of 9/11. It is also inevitable that another field of enquiry, globalisation studies, should be applied to understanding 9/11. Even if this field might not yet be confident or established enough in its individual status to generally speak of itself in upper case terms, in the discussions amongst both policy and academic circles post-9/11 there was a definite sense in which these events were related to the phenomenon of globalisation, and that those engaged in its study may possess a distinct type of knowledge that could contribute to the debate on security.

The argument of this article is that the study of globalisation does indeed have the capability to make a distinctive and advantageous, if at times supplementary, contribution to the study of security after 9/11. It argues that the processes of globalisation themselves, defined in a variety of ways including liberalisation, convergence and supra-territorialisation, form one conceptual lens and explanation for the perpetration of and responses to violent conflict and terrorism. Although, at the same time, this article argues that globalisation alone is not responsible for conflict scenarios such as that in Afghanistan, but needs to be understood in combination with other fundamental or 'conjunctural' shifts in the international structure, including decolonisation and bipolarisation.

The study of globalisation is inherently a multidisciplinary enterprise, drawing in IR, International Political Economy (IPE), Economics, Sociology, History and a number of other fields of expertise. This type of approach is arguably less constrained by traditional state-centred security debates, and is thus highly suited to getting to grips with the complex and cross-cutting security agenda after 9/11. It offers a means to address its multi-actor nature in terms of the revealed (if not wholly new) 
proliferation of security actors; its multi-dimensional nature in comprising politicalmilitary, economic, societal and environmental security; its multi-regional nature in straddling and connecting the security of a number of regions from the Middle East, to Africa, Europe, East Asia; and its inter-linked nature in seeing all of these actors, dimensions, and regions as potentially conjoined and impacting on the security of each.

Alongside this exhortation to consider the post-9/11 security agenda as one which can be seen in many ways as something akin to a post-globalisation security agenda, this article also throws in three major caveats that limit its scope and ambition. Firstly, there is always the constant danger of over-stretching both the concepts of globalisation and security to the point of losing sharpness in their conceptual definition and explanatory power. Susan Strange chided the globalisation studies community by remarking that the phenomenon has been used to analyse everything from the Internet to the hamburger, ${ }^{1}$ and this serves as a warning that we should be cautious in applying globalisation to the topic of security, an already well developed field. There is a risk on various sides of debate of engaging in a 'securitisation' exercise and simply slapping the label of globalisation on 9/11 without delving any deeper in our analysis. ${ }^{2}$ Those who perceive themselves as victims of the attacks may argue that terrorism is an anti-globalisation force, but this is a statement, as argued below, that can only penetrate to the truth if globalisation is carefully defined from different perspectives to discover the particular elements of this broad phenomena that the perpetrators of terror are resisting. Meanwhile, those who perceive themselves as victims of globalisation and its related evils, or in the policy and academic communities that argue the case in favour of such perceived victimisation, may have hit upon globalisation as a genuine force for generating insecurity. However, if this is as far as the examination of the globalisation-security nexus goes, then this runs the risk of caricaturing globalisation and halting in its tracks debate that can unpack the phenomenon and its political and economic dynamics, and in turn the effort to understand in a deeper fashion the interconnection with security. Unfortunately, this deeper understanding of 9/11 has not been overly present in much of the related analysis, with a knee jerk reaction on all sides of locating security with the globalisation process but without actually examining what the term itself means in different contexts.

Secondly, this article should be read with the caveat that it will touch upon events in the Middle East, but that the author is more knowledgeable about security studies and globalisation in general and with particular reference to the East Asia region. Thirdly, this article cannot attempt to cover all the events and implications of 9/11 simply due to the massive scope of the agenda and the limited number of words available.

Nonetheless, having outlined these caveats and the risks involved, this article will briefly introduce some areas where the study of globalisation may add explanatory power to the events of 9/11 and the current attempts of Security Studies to grapple with its implications. The problem of conceptual clarity will be overcome by attempting to adopt a two-level definition of globalisation that will highlight how it

\footnotetext{
${ }^{1}$ Susan Strange, The Retreat of the State: The Diffusion of Power in the World Economy, Cambridge, Cambridge University Press, 1996, p. xiii.

${ }^{2}$ For examples of the debate on securitisation, see Barry Buzan, Ole Waever, Jaap de Wilde, Security: A New Framework for Analysis, Boulder, Colorado, Lynne Rienner, 1998, pp. 23-26; and Simon Dalby, 'Contesting an Essential Concept: Reading the Dilemmas in Contemporary Security Discourse', in Keith Krause and Michael C. Williams, eds., Critical Security Studies: Concepts and Cases, Minneapolis, University of Minnesota Press, 1997, pp. 3-32.
} 
impacts on security. The problem of how far to stretch the interconnection between globalisation and security will also be addressed by limiting the examination to the ways in which globalisation phenomena have impacted on the generation of and responses to violent conflict, rather than in this particular context running the whole gamut of potential security problems opened up by globalisation. The minimal knowledge of the Middle East cannot be readily overcome, but the strategy of the article is on the one hand to hope that some of the lessons about the impact of globalisation on East Asia are transferable to other regions, and, on the other, to simply hope that some of the insights offered resonate with those more expert in this region. Finally, as all events and implications of 9/11 cannot be dealt with, the approach of the article is simply to sample a variety of areas where globalisation has impacted on security and the problems of terrorism and state responses.

\section{Defining Globalisation}

\section{Globalisation as Liberalisation and Convergence}

Globalisation is a notoriously slippery concept to define. This article suggests a twostep definition and understanding of globalisation as both reflexive and substantive processes which are dialectically related and in many cases nearly indistinguishable. Perhaps the most common understanding of globalisation to date has been that of internationalisation, implying the increasing density and interdependence of interaction amongst nation-states and their markets, or, more accurately, given the lack of congruence in many regions between state entities and their nationalist populations, sovereign-states. In turn, these increased flows of capital, personnel and knowledge generally go beyond internationalisation, which implies the state essentially remaining unchanged in this process, and involves the lowering of state borders, which then equates to the process of liberalisation. ${ }^{3}$

The next most common definition of globalisation is derived from the general notion prevalent in the mass media and mass opinion of a general convergence in global affairs in the economic, political and other spheres of social activity. The convergence thesis view of globalisation finds its most extreme form in the hyperglobalisation and 'end of history' literature of the likes of Kenichi Ohmae and Francis Fukuyama. ${ }^{4}$ However, the convergence thesis also feeds through in a variety of extremes into definitions of globalisation that revolve around the idea of the universalisation of standards of social interaction. This is at least the preferred understanding in the discourse of many of the most powerful government and institutional advocates of the benefits of globalisation in the developed world. For even if they may not argue consciously for universalisation and wish to acknowledge heterogeneity, the economic policies and Structural Adjustment Packages (SAP) which the international financial institutions (IFI) have championed for the developing world in East Asia, Latin America, Africa and the Middle East imply at the very least convergence by default. From the developing world view, such policies which lead to convergence and universalisation can also bring about a definition of globalisation as Westernisation. Even less attractive is the concept of globalisation as

\footnotetext{
${ }^{3}$ For this type of understanding of globalisation in government circles as internationalisation and liberalisation, see UK Government, Eliminating World Poverty: Making Globalisation Work for the Poor, White Paper on International Development, December 2000, http://www.globalisation.gov.uk/WhitePaper/FullPaper.pdf.

${ }^{4}$ Kenichi Ohmae, The Borderless World, London, Fontana, 1990; Francis Fukuyama, The End of History and the Last Man, Harmondsworth, Penguin, 1992.
} 
a form of Americanisation, as the US is seen as the principal power pushing for convergence in ways that only serve to reinforce its global political and economic dominance, and that are capable of leading to accusations of neo-imperialism. ${ }^{5}$ The implications for security of the perceived congruence between globalisation and Americanisation in the generation of anti-American feeling in the case of 9/11 is addressed in subsequent sections.

\section{Globalisation as Supra-territorialisation}

Liberalisation, universalisation, Westernisation, and Americanisation are all clearly components of globalisation, and because globalisation is itself a reflexive process (often accentuated by modern telecommunications technology), where perceptions drive forward the process, this means that these definitions and their related discourses are not merely academic matters but have to be dealt with as world views that motivate actual political, economic and security behaviour. However, it is also possible to conceive of globalisation at a second and still higher conceptual level, and which can help to further unlock understanding of its impact upon security. Arguably, the above definitions fail to capture the qualitatively different nature of globalisation from other processes and phenomena associated with the interaction of social forces on a global scale. Globalisation represents a qualitatively different process due to its essential de-territorialisation, or stated in reverse, supra-territorialisation of social interaction. That is to say, globalisation is a process which increasingly reconfigures social space away from and beyond notions of delineated territory, and transcends existing physical and human borders imposed upon social interaction. ${ }^{6}$ For instance, global financial transactions, facilitated by information technology, can now often operate without reference to physical territorial distance or human-imposed territorial barriers. Hence, globalisation is a process facilitated by economic liberalisation and the growth of new technologies, but it is a process which may also go beyond these in its functioning and outcomes. Again, it is important to avoid the 'hyper-globalisation' thesis which views the world as moving towards a condition of being totally 'borderless'. For it is apparent that there is considerable territorial 'drag' upon the free-flow of globalisation forces; that not all forms of economic interaction such as trade and labour migration are as fully globalised as finance; that there are wide disparities in the degree of globalisation across different regions of the world; and, as pointed out in subsequent sections, that there is both resistance to and reversibility in the process itself. ${ }^{7}$ Nevertheless, globalisation as a process of supra-territorialisation is increasingly affecting large sections of the world, and must be acknowledged as a different, although certainly related, process to those other definitions of social interaction noted above. Hence, even though liberalisation, internationalisation, universalism, and Westernisation may eventually result in globalisation, the fact that they may not necessarily be entirely detached from territorialisation means that they remain on a qualitatively different level to the inherently supra-territorial phenomena of globalisation.

\footnotetext{
${ }^{5}$ For one critical view from the developing world of globalisation as leading to the reinforcement of the power of the North over the South, see Martin Khor, Globalization and the South: Some Critical Issues, Penang, Third World Network, 2000, pp. 1-16.

${ }^{6}$ Jan Aart Scholte, 'Global Capitalism and the State', International Affairs, vol. 73, no. 3, July 1997, p. 431.

${ }^{7}$ For a cautiously skeptical view of the extent of globalisation, see Paul Hirst and Grahame Thompson, Globalisation in Question, Cambridge, Polity Press, 1999, pp. 1-18.
} 
The phenomena of globalisation as supra-territorialisation and the reconfiguration of social space carries significant implications for existing forms of social organisation, and, most importantly in the case of security issues, the dominant position of the nation-state within the existing globality. Needless to say, the state with its exclusive jurisdiction-or in other words, sovereignty-over a particular social and territorial space, delineated by a combination of physical geography and most especially human construction, has been the basic unit for the division of global space in the modern era. States in the past have attempted in theory and practice to exercise sovereign control over all forms of social interaction in the political, economic, and security dimensions, both within and between their territorial borders. Quite clearly, and as elucidated below with reference to the post-colonial states of East Asia and the Middle East, not all states throughout history have been strong enough to be able to exercise the same degree of sovereign control and authority over all forms of social interaction. Nevertheless, sovereign-states rooted in territorial notions of social space have been the prime unit for facilitating, impeding and mediating interaction between the societal groups, organisations, and citizens and other categories of collective and individual societal units contained within their borders. Hence, to date, global social space has been primarily international, or intersovereign-state, social space.

However, the inherent nature of globalisation as a process which transcends and overrides territoriality as the dominant principle for the organisation of social space now poses a fundamental challenge to the sovereign-state as the basic social unit which exemplifies and undergirds this very territorial principle. Sovereign-states must contend with the freer flow of social forces on a global scale which move with declining reference to the previous limitations and channels imposed by state borders. This increasing porosity of state borders, relative decline in the de facto sovereign authority of states over social interaction, and corresponding increased exposure of 'internal' societal groupings to 'external forces' (or even indeed the removal of the traditional domestic-international divide to create an inter-mestic arena for social interchange) has a number of outcomes for security discussed below. For if global social space has been primarily international or inter-sovereign-state space for much of the modern era, then the security order as one aspect of social interaction has been primarily built around the inter-state order. But it is clear that the security order is now pitted against the phenomenon of globalisation which generates security issues diametrically opposed to and often beyond the limits of sovereign-state authority.

\section{Globalisation and Security}

The following sections now attempt to examine how globalisation, understood in terms of liberalisation, convergence, and supra- or de-territorialisation, can be seen to motivate and facilitate the contemporary security agenda and generation of violence in both general terms and with specific reference to 9/11.

\section{Sovereign-state Units, Decolonisation, Bipolarisation, and Globalisation}

The influence of globalisation needs to be considered alongside other major processes which have shaped the inter-sovereign-state and related security system. The effects of globalisation should not be disembedded from factors of historical and regional contingency, and, following on this, the particular nature of the state units in each 
region which underpin (or in many case are increasingly failing to underpin) the global security order. In order to understand these state units it is thus necessary to remember that, prior to the advent of globalisation as the dominant perceived trend in regional politics, the forces of decolonisation and bipolarisation were the most active in shaping sovereign-states in the post-war period, and that these forces clearly had differential effects. In the developed world, decolonisation clearly figured less greatly in the reconfiguration of already well-established individual state units, many of which were colonisers themselves, other than to reorder their relative capacities in the inter-sovereign-state system. Bipolarisation served to preserve these sovereign-state units, if to skew the economic development of the states of the communist and noncommunist camps. In the developing world, the effects of decolonisation and bipolarisation were more fundamental. ${ }^{8}$ Decolonisation in Africa, East Asia and the Middle East brought into existence a number of new sovereign-states. In theory these were modelled along the lines of the sovereign and nation-states of their former colonial masters or the developed states, but in practice have not always conformed to these ideals. In many instances, the idea of the sovereign-state came before or diverged from that of the nation-state: shown by the fact that the territorial and sovereign space of states in the region was often delineated along former colonial borders which had been drawn arbitrarily and in contradistinction to trans-border ties of ethnicity and religion.

These problems are particularly salient in East Asia and the Middle East, where cross-border minority groups such as the Palestinians, Kurds, Chechens, Karens and Timorese are often at loggerheads with the state into which they have been principally incorporated. Such contradictions between sovereign space and societal composition clearly weakened from the start the internal political cohesion of states in the region, and laid the ground for the potential divisibility between the security interests of the state and its societal constituents. Hence, these types of states have often been subject to internal political unrest, separatist and insurgency movements. Moreover, the common legacy of distorted development from the colonial period also placed these states in a disadvantageous economic position to maintain their internal stability. For instance, the preoccupation of many states in the East Asia region since the post-colonial has been to preserve their internal integrity by advancing the process of state-building, and particularly in the economic sphere, as a means to reconcile these structural contradictions. ${ }^{9}$ In the Middle East, the picture is a similar one of the forced economic integration of this region into the international political economy under the influence of the imperial powers, and then the continuing legacy of the structural dependence on raw material and oil exports and limited intraregional economic integration in the post-colonial period-all obliging the regimes of region to attempt to secure their legitimacy by state-led development policies.

The problematic position of newly-established sovereign-states in various regions was also further compounded either during or immediately after the decolonisation phase by the impact of the onset of the Cold War. The division of regions between the competing ideologies and political economies of the socialist and capitalist blocs was to create a legacy of military confrontation and superpower interventionism. Just as important when considering the post-globalisation security

\footnotetext{
${ }^{8}$ For an approach which combines the processes of decolonisation and globalisation to explain development across different regions, see Ankie Hoogvelt, Globalization and the Postcolonial World: The New Political Economy of Development, Basingstoke, Palgrave, 2001.

${ }_{9}^{9}$ Mohammed Ayoob, The Third World Security Predicament: State Making, Regional Conflict and the International System, Boulder, Colorado, Lynne Rienner, 1995, pp. 21-45.
} 
agenda is the effect of the Cold War upon the state building-agendas and development of the political economies of many of the states in the East Asia and Middle East regions. The economic dispensations offered by the superpowers to allied, aligned, or even non-aligned states in various regions of the developing world assisted their economic progress but also left them ultimately vulnerable to fundamentally vulnerable when exposed to the forces of liberal capitalism at the end of the Cold War.

Therefore, the overlapping processes of decolonisation and bipolarisation have had a significant impact upon the development of the sovereign-states of the developing world and their ability to respond to the process of globalisation. Firstly, these processes have created states marked by internal contradictions between the delineation of territorial space and societal composition, and a near ineradicable and potential divisibility between the proclaimed security interests of these states and large sections of their citizenry. Secondly, they have created states that are or will be increasingly driven to exploit the benefits of liberal capitalism to paper over the political and security cracks in their own societies, but which have been insulated in the past from the full effects of capitalism's tendency towards periodic crises. The end of the Cold War and the declining incentives on the part of the US to provide special economic dispensations is also exposing the states of various regions to fully-fledged modes of liberal capitalism and their attendant security costs. In East Asia the end of US dispensations was highlighted to some degree by its unwillingness to invest significant resources in bailing out the East Asia states from the financial crisis of 1997 onwards. In the Middle East, it seems the end of the Cold War and collapse of oil prices for the oil producing countries generated major economic shocks, whilst the decline in US and Soviet technical, military and economic aid undermined the economic stability of oil and non-oil producing Arab states alike. ${ }^{10}$

\section{Motivations for Violent Conflict}

The analysis above of the processes of decolonisation and bipolarisation provides an historically contingent backdrop which helps to explain how globalisation processes impact on security across different sovereign-states and societies. If the first stage definition of globalisation as liberalisation is applied, it is immediately apparent how these processes have impacted on the political economies of a variety of states, which in turn has produced the conditions for violent conflict. Economic liberalisation in East Asia has produced mixed effects for economic and political stability. Firstly, globalisation has produced economic exclusion for states and individuals. This may be marked by disparities in welfare, which can feed through into military tension amongst states, or result in internal unrest within states. North Korea is one example of a state which has taken the path of autarchy and found itself lagging behind other states in the region economically. ${ }^{11}$ Secondly, globalisation may produce economic rivalry amongst states and their citizens for scarce economic resources, a constant potential problem in East Asia with regard to competition for energy, food and fresh water resources. Thirdly, globalisation may produce economic dislocation within states. In East Asia, this location has been marked by financial crises and the

\footnotetext{
${ }^{10}$ Toby Dodge, 'Bringing the Bourgeoisie Back in: Globalization and the Birth of Liberal Authoritarianism in the Middle East', in Toby Dodge and Richard Higgott, eds., Globalization and the Middle East: Islam, Economy, Society and Politics, London, Royal Institute of International Affairs, 2002, p. 181.

${ }^{11}$ Christopher W. Hughes, Japan's Economic Power and Security: Japan and North Korea, London, Routledge, 1999, pp. 117-160.
} 
ingraining of poverty in certain sections of society. All these effects of economic liberalisation and globalisation are accentuated by the pre-existing vulnerabilities engendered by the effects of decolonisation and bipolarisation on the political economy of development in such states, and can feed through into social instability. In turn, these problems of instability are compounded by the often declining ability of states under the dominance of neo-liberal IFIs to practice policies which can redistribute these costs away from the most vulnerable in their societies and minimise internal political tensions.

In the Middle East it would appear that globalisation in the form of economic liberalisation has produced similar effects. The oil producing states of the region are in a sense already globalised due to their high degree of dependence on the export of one commodity, but have also been able to insulate themselves to a certain degree due to their large market share and the converse dependency of foreign consumers on their products. However, it is also clear that states such as Saudi Arabia that have been able to practice a degree of autarchy in the past, which has also reinforced the autocracy of the ruling regime, are now facing a decline in their economic performance.

Subsequently this presents such states with the need to further liberalise their economies to attract foreign direct investment (FDI), but this presents the dilemma of exacerbating potential internal inequalities in welfare, the exposure to external economic shocks, and the resulting political risks of divergent calls for both greater reform or to reverse reforms. This provides fertile ground for political discontent with the dominant regimes, and the radicalisation of Islam which forms the only outlet for the expression of opposition in states where political parties are banned or subjugated to the state. Recent bomb attacks in Saudi Arabia in early 2002, directed against foreigners, are evidence of the rising dissatisfaction with the Western-oriented but also politically rigid House of Saud. For the non-oil producing states, these dilemmas are even greater as they are possessed of fewer resources to cushion the economic and political impact of their integration into the global political economy.

Likewise, globalisation perceived as convergence, leading to Westernisation or Americanisation, clearly possesses also the potential to create an environment conducive to political discontent. In East Asia, the confidence that many of the elites possessed in the prowess of their own economic management to simultaneously ride the wave of economic globalisation and to maintain the allegedly common bulwark of 'Asian Values' against the encroachment of 'Western Values' accompanying economic development, has met a serious setback. The perceived dominance of the US over IFIs and its attempts to rollback the developmental state model in the region, resulted in resentment in varying degrees towards the US and West amongst both political leaders and on the 'street' amongst the disadvantaged. ${ }^{12}$ In the case of Indonesia and Malaysia, the financial crisis also raised the fears that moderate or secular governments may not be able to hold the line as anti-globalisation and antiWestern sentiment combined with the radicalisation of Islam. ${ }^{13}$ Regarding the situation in the Middle East, there has always been strong to intense strains of antiWesternism amongst regime elites and the general population. But it would appear

\footnotetext{
${ }^{12}$ Christopher W. Hughes, 'Japanese Policy and the East Asian Currency Crisis: Abject Defeat or Quiet Victory?’, Review of International Political Economy, vol. 7, no. 2, Summer 2000, pp. 232-233; Richard Higgott, 'The Asian Economic Crisis: A Study in the Politics of Resentment', New Political Economy, vol. 3, no. 3, pp. 333-356.

${ }^{13}$ For an analysis of the impact of the East Asian financial crisis on the Indonesia and Malaysian political economies and domestic politics, see Joseph A. Camilleri, States, Markets and Civil Society in the Asia-Pacific: The Political Economy of the Asia-Pacific Region, Volume 1, Cheltenham, Edward Elgar, 2000, pp. 262-290.
} 
that the concerns associated with globalisation can only add to the impetus to the backlash against the West and globalisation, and the US as their dominant champion.

Meanwhile, technology, and especially information technology, as the one of the drivers of globalisation has also served to reinforce these potential antiglobalisation sentiments by enabling the rapid dissemination about its effects to elites and masses alike. It would be too crude an assessment to state that globalisation has provided the only motivations for 9/11 and that its role can be conceived of as laying the grounds for the 'clash of the civilisations'. Samuel Huntington's thesis is certainly problematic in seeking to establish distinct cultures diametrically opposed to each other and bound to generate conflict. ${ }^{14}$ Moreover, it would be simplistic to ascribe $9 / 11$ to being purely a reaction to globalisation. It is clear that opinions on globalisation in the Middle East are divided between those which see their world as already globalised-Islam being the true form of global religion - and those that view globalisation as the inherent threat of convergence, universalisation, Westernisation and Americanisation. ${ }^{15}$ Nevertheless, globalisation's role in challenging the existing state dominance of the political economies of Middle Eastern societies, its perception as leading to convergence, and its ability to project these perceptions into the elite and popular 'global consciousness' (to abuse Roland Robertson's terminology which argues for the closure rather than exposure of cultural cleavages) through media organisations such as the satellite broadcasters CNN and al-Jazira, all argue that it has been a contributory factor in the rise of radical Islamic sentiment that found one motivation and expression in the terror of $9 / 11 .{ }^{16}$ In this sense, globalisation's impact on security may be seen to follow the Huntington thesis more than that of Fukuyama, even if the latter's predictions on convergence may be one principal motivating factor for conflict.

\section{Facilitation of Conflict}

Globalisation defined as liberalisation, convergence and its higher definition of supraterritorialisation, also offers a perceptual tool for understanding how terrorist acts such as 9/11 have been facilitated. In terms of actors, globalisation's challenge to sovereignty opens up a range of new political identities for non-state actors in the global political economy. As noted above, the attempt to construct states that control social interaction within a delimited territorial space has also often meant attempt to shoehorn political identities within this state construction. Most typically this construction has been underpinned by the close association between the state and its citizenry in the form of nationalism. However, this association between the apparatus of the state and its population is clearly challenged by globalisation as a process of economic liberalisation which transcends sovereign borders and the capacity of states to deal with trans-sovereign problems. The result of this can be for the citizenry of states to look to alternative political identities distanced from the sovereign-state and inter-sovereign-state systems. These new identities may take the form of nationalism which transcends state borders, leading to problems of separatism of irredentism. It may also take the form of non-state-centred forms of political identity and activity.

\footnotetext{
${ }^{14}$ Samuel P. Huntington, 'The Clash of the Civilizations?’, Foreign Affairs, vol. 72, no. 3, 1993, pp. 22-49.

${ }^{15}$ Fred Halliday, 'The Middle East and the Politics of Differential Integration', in Dodge and Higgott, Globalization and the Middle East, pp. 42-45.

${ }_{16}$ Roland Robertson, Globalization: Social Theory and Global Culture, London, Sage Publications, 1992, pp. 8-9.
} 
The most positive manifestation of this movement is often viewed as the growth of what has been termed as 'global civil society' to complement efforts at global governance, manifested in the increasing policy input of Non-Governmental Organisations (NGO). ${ }^{17}$ More worrying from the Western perspective has been the rise of global 'uncivil society', whereby individuals and groups can forge a common cause across sovereign-state boundaries. These groups may consist of trans-sovereign crime groups which enjoy a form of political identity, as in the separatist groups in Burma which fund their campaign from the narcotics campaign. ${ }^{18}$ But they may also have a sharper political identity still and have a strong trans-sovereign movement with implications for security. ${ }^{19}$ Arguably, the Al Qaeda network is one such movement, which draws it strength to some degree from traditions of pan-Arabism and a common Islamic identity, and is facilitated by the rise of globalisation which engenders and enables the articulation of such a trans-sovereign political and cultural identity.

In addition, globalisation has manifestly also facilitated the actual terrorist activities of Al Qaeda. Globalisation, again in conjunction with the effects of decolonisation and bipolarisation, has eroded the sovereignty of states, and it is in the areas where the sovereign control of states is weakest-most notably Afghanistan and Somalia-where terrorist networks have accumulated. For such states are where the remit of the central government often fails to run and where groups can practice illicit activities relatively free from interference. Beyond providing a conceptual map to identify sites of the basing of terrorists, globalisation also enhances our understanding of the means by which these networks are able to operate within other societies. Globalisation as economic liberalisation and the transcendence of sovereign control over social interaction, spurred on by improvements in transportation and information technology, has enabled trans-national crime and terrorist organisations to mimic the behaviour of transnational corporations (TNC), and to move with greater ease across deregulated economic and territorial space. ${ }^{20}$ Terrorist organisations are also now able to strike against their targets without even necessarily an attack on their territory per se. In the case of the US, the defence of its homeland now comprises its physical sovereign territory and the extension of its economic presence to the domain of cyberspace engendered by modern telecommunications technology. In this way, $\mathrm{Al}$ Qaeda has been able to exploit the open societies of the West to perpetrate terror, and to gain the resources to do through money laundering and the partial exploitation of globalised financial networks. ${ }^{21}$ As President George W. Bush noted in a speech to Congress on 20 September 2001, terrorist organisation such as Al Qaeda have now acquired 'global reach'. 22

\section{Responses to $9 / 11$}

\footnotetext{
${ }^{17}$ Jan Aart Scholte, Global Civil Society Changing the World?, Centre for the Study of Globalisation and Regionalisation, University of Warwick, Working Paper, no. 31, 1999.

${ }^{18}$ Christopher W. Hughes, 'Conceptualizing the Globalization-Security Nexus in the Asia-Pacific', Security Dialogue, vol. 32, no. 4, December 2001, p. 416.

${ }^{19}$ Mary Kaldor, New and Old Wars: Organized Violence in a Global Era, Cambridge, Polity Press, 1999, pp. 6-7.

${ }^{20}$ Stephen E. Flynn, 'The Global Drug Trade Versus the Nation-State’, in Maryann K. Cusimano, ed., Beyond Sovereignty: Issues for a Global Agenda, Boston and New York, Bedford/St. Martin’s, 2000, p. 52.

${ }^{21}$ For a prescient discussion prior to 9/11 of how terrorist networks such as al-Qaeda could exploit the opportunities of a globalising world, see Steven Simon and Daniel Benjamin, 'America and the New Terrorism', Survival, vol. 42, no. 1, Spring 2000, pp. 59-75.

${ }^{22}$ Cited in International Institute for Strategic Studies, Strategic Survey 2001/2002, Oxford, Oxford University Press, 2002, p. 231.
} 
The response of the US and other coalition states to 9/11 also provides interesting insights into the interconnection between understandings of globalisation and the contemporary security agenda. One observation that has emerged from recent events after $9 / 11$ is that the onset of globalisation is neither inevitable nor irreversible, and thus its impact on security can also be channelled and shaped. Contrary to the predictions of the hyper-globalists, the sovereign-state retains considerable flexibility to not only take a transformationalist path under conditions of globalisation, but also to firmly re-orient or even reverse the process if necessary. The concerted action by the US and its allies against international money laundering is one demonstration that the sovereign-state, especially in the developed world, lives on and still possesses considerable resources to respond to trans-sovereign terror movements.

At the same time, the response of the US to 9/11 provokes the observation that globalisation and security are interconnected in terms of the increasing globalisation of military strategy. This occurs not just in the domain of the US ability to co-ordinate a global coalition stretching from Europe and even to Japan, with more passive support from the likes of China, but also to its ability to project its own military power unilaterally. If globalisation is conceived of as the transcendence of territorial and sovereign barriers, then US military action can be depicted in certain ways as the apogee of this. The US in the Afghan campaign has certainly demonstrated its progression, again driven by the leveraging of advanced technology, towards being able to exercise power with declining reference to geographical distance and time, and across the four dimensions of land, sea, and especially air and space. For instance, US commanders were able to deploy unmanned aerial vehicles (UAV) to gather real time information on enemy activities and to enable real time responses. In this sense, the US has moved one step closer to the realisation of the long-envisaged Revolution in Military Affairs (RMA) and the global reach of its power to match that of its terrorist counterpart. ${ }^{23}$

The conflict in Afghanistan, though, has also demonstrated that the US has still not affected a totally globalised or post-modern military strategy. The US was not entirely free from territoriality in projecting its power in the Middle East, intent as it was to secure bases for its military forces in Saudi Arabia (unsuccessfully) and in the central Asian republics (with more success) for the assault on Afghanistan. The US was also forced to fight a ground war for the possession of territory, even if this was limited to the deployment of its own and coalition special forces, as well as the Northern Alliance as a proxy ground army. Above all, the US may have been able to limit its own engagement on the ground and resulting casualties, but its military campaign in traditional fashion wreaked untold devastation and pain on its enemies and non-combatants in Afghanistan. ${ }^{24}$

\section{Conclusion: Globalisation and Future Responses to Insecurity}

This article has argued that globalisation provides a number of conceptual insights to assist understanding of the contemporary security agenda following 9/11. Differing definitions of globalisation, individually or in combination, can shed light on the motivations and facilitation of, as well as the responses to, the activities of al-Qaeda

\footnotetext{
${ }^{23}$ For US global military strategy and the RMA, see Paul Rogers, Losing Control: Global Security in the Twenty First Century, London, Pluto Press, 2000, pp. 58-77; Michael O’Hanlon, Technological Change and the Future of Warfare, Washington D. C., Brookings Institution Press, 2000, pp. 7-31.

${ }^{24}$ On the likelihood that globalisation will not necessarily engender a reduced casualty environment for modern warfare, see Ian Clark, Globalization and International Relations Theory, Oxford, Oxford University Press, 1999, p. 115.
} 
and other extant forms of terrorism. Globalisation as liberalisation engenders tensions in the political economy of societies, which, when synergised with globalisation as the perception of convergence and Westernisation, can lay down the motivations for conflict. In turn, the actualisation of these conflicts is enhanced by globalisation as economic liberalisation and trans-territorialisation which enable terrorist groups to exploit areas of weakening sovereignty and to extend their activities along the same economic networks that are utilised by other agents of globalisation such as TNCs. The response of the US and other states to 9/11 also provides insights into the globalisation-security nexus. Globalisation, although it can generate security problems, can also be mastered by the developed states and its worst security excesses curbed given sufficient political will and urgency. Lastly, 9/11 is a demonstration of the increasing globalisation of military strategy and power, but simultaneously its continuing limitations.

These observations lead to a final thought about the direction which the post9/11 and post-globalisation security agendas may take. 9/11 has indeed demonstrated the ability (or at least the effort) of the developed states to channel globalisation in their interests, to tame factors such as international finance, and to reverse the retreat of the state. If these states are intent on reshaping globalisation processes then they may have also hit upon the key to addressing the root causes of the political economy of insecurity that can give rise to the hyper-terrorism of Al Qaeda. However, the concern must be that the developed states have only learned a partial lesson from 9/11. Despite all the talk of state-building in Afghanistan, in other areas of international policy the leading powers continue to adhere to policies of globalisation which are, as noted above, more oriented towards state-reducing. Therefore, unless there is an effort to harmonise globalisation with the as yet unfinished state-building efforts of other regions, then there will be no solution to trans-sovereign terrorism. Moreover, the meaning of state-building here should not be construed as simply Cold War-style Western support for the rigid and autocratic regimes of the Middle East, but an effort to move beyond the status quo and nurture the indigenous development of states that will best allow them to filter the benefits of globalisation whilst undergoing the transformation towards modernity. Added to this, 9/11's confirmation of the ability of not only terrorist networks to transcend sovereignty but also major states such as the US to project power in a globalised fashion does not provide hope for easy solutions to global insecurity. For as long as the US defence community continues to possess the (perhaps mistaken) perception that it can tackle global terrorism with globalised military power, and thus pursue technical rather than genuine political solutions to the threat of terrorism, then insecurity and the threat of terrorism will persist. 